\title{
PENEGAKAN HUKUM SEBAGAI UPAYA MENINGKATKAN PENDAFTARAN DAN PENCATATAN KEKAYAAN INTELEKTUAL DI INDONESIA
}

\author{
Budiman N.P.D Sinaga', Baru Tulus Obtain Siambaton ${ }^{2}$, Adirman Budi Nduru ${ }^{3}$ \\ Program Studi Ilmu Hukum dan Magister Hukum \\ Universitas HKBP Nommensen, Medan-Sumatera Utara-Indonesia \\ e-mail: budiman.sinaga@uhn.ac.id
}

\begin{abstract}
Currently, registration and registration of intellectual property in Indonesia are still deficient compared to other countries. Therefore, it is necessary to research the registration and recording of intellectual property that is still low and efforts to improve the registration and recording of intellectual property in Indonesia. This study wants to find out the cause of registration and recording of intellectual property so that the required data is secondary data and primary data. Therefore, this research used normative and sociological legal research methods together to be able to complement each other. Based on the results of the study can be concluded as follows. Registration and recording of intellectual property in Indonesia are still low because the public does not know much about registration and recording. Also, the public feels free to do registration and recording because the enforcement of intellectual property law is still low as law enforcement is still not firm in the event of piracy of intellectual property. Various efforts have been made to increase the registration and recording of intellectual property in Indonesia, among others, through the enforcement of intellectual property laws that are getting better and registration and recording of intellectual property that is getting easier and cheaper.
\end{abstract}

Keywords: Law Enforcement, Registration, Recording, Intellectual Property.

\begin{abstract}
Abstrak
Sampai saat ini pendaftaran dan pencatatan kekayaan intelektual di Indonesia masih sangat rendah dibandingkan dengan negara-negara lain. Sehubungan dengan itu perlu diteliti mengenai pendaftaran dan pencatatan kekayaan intelektual yang masih rendah serta upaya meningkatkan pendaftaran dan pencatatan kekayaan intelektual di Indonesia. Penelitian ini hendak mengetahui penyebab pendaftaran dan pencatatan kekayaan intelektual sehingg data yang diperlukan tidak hanya data sekunder melainkan data primer juga. Oleh karena itu, dalam penelitian ini digunakan metode penelitian hukum normatif dan sosiologis secara bersama-sama untuk dapat saling melengkapi satu sama lain. Berdasarkan hasil penelitian dapat ditarik kesimpulan sebagai berikut. Pendaftaran dan pencatatan kekayaan intelektual di Indonesia masih rendah karena masyarakat belum mengetahui banyak mengenai seluk beluk pendafataran dan pencatatan. Selain itu, masyarakat merasa percuma melakukan pendafataran dan pencatatan karena penegakan hukum kekayaan intelektual masih rendah seperti masih belum tegas penegakan hukum dalam hal terjadi pembajakan atas kekayaan intelektual. Ada beberbagai upaya yang sudah dilakukan untuk meningkatkan pendaftaran dan pencatatan kekayaan intelektual di Indonesia, antara lain melalui penegakan hukum kekayaan intelektual yang semakin baik serta pendafataran dan pencatatan kekayaan intelektual yang semakin mudah dan semakin murah.
\end{abstract}

Kata Kunci: Penegakan Hukum, Pendaftaran, Pencatatan, Kekayaan Intelektual. 


\section{A. Pendahuluan}

Sampai saat ini pendaftaran dan pencatatan Kekayaan Intelektual (KI) di Indonesia dapat dikatakan masih sangat rendah dibandingkan dengan negara-negara lain. Di negara lain, terutama negara-negara maju, pendaftaran dan pencatatan KI sudah diyakini sebagai seseuatu yang penting bahkan sangat penting. Di sana orang atau badan hukum yang memiliki KI sudah secara suka rela mendaftakan atau mencatatkan KI. Kenyataan yang berbeda bahkan bertolak belakang terjadi di Indonesia. Di sini orang atau badan hukum masih lebih banyak yang enggan melakukan pendaftaran atau pencatatan KI daripada orang atau badan hukum yang sudah sadar sehingga secara sukarela melakukan pendaftaran atau pencatatan.

Sampai sekarang di Indonesia sangat sedikit, kalau tidak mau dikatakan tidak ada sama sekali, orang atau badan yang secara suka rela mendaftarkan atau mencatatkan KI. Kalaupun ada yang mendaftarkan atau mencatatkan kebanyakan karena dipaksa atau keharusan seperti para dosen yang memperolah hibang penelitian diwajibkan mendaftarkan atau mencatatkan hasil penelitian mereka. Kemungkinan lain pendaftaran atau pencatatan itu dilakukan berkaitan dengan program Pemerintah, misalnya pencatatan atau pendafataran yang dilakukan Badan Ekonomi Kreatif (Bekraft) pada beberapa tahun yang lalu.

Ada banyak alasan dan kendala yang dapat dikemukakan untuk membenarkan pendaftaran dan pencatatan KI yang masih rendah di Indonesia. Salah satu kendala dalam memperoleh hak kekayaan intelektual adalah ketidaktahuan para penemu/pengrajin, atau pencipta atas proses pencatatan atau pendaftaran untuk mendapatkan hak di Dirjen HKI. Selain itu, banyak orang yang menjadi malas melakukan pendaftaran atau pencatatan KI karena melihat penegakan hukum di bidang KI ini sangat lemah. Adapun kendala atau problem dalam penegakan hukum menurut Sanyoto ${ }^{2}$ meliputi hal-hal berikut ini:

1. Problem pembuatan peraturan perundangundangan.

2. Masyarakat pencari kemenangan bukan keadilan.

3. Uang mewarnai penegakan hukum.

4. Penegakan hukum sebagai komoditas politik,

5. penegakan hukum yang diskriminatif dan ewuh pekewuh.

6. Lemahnya sumberdaya manusia.

7. Advokat tahu hukum versus advokat tahu koneksi.

8. Keterbatasan anggaran.

9. Penegakan hukum yang dipicu oleh media masa.

Pada saat ini pembidangan hukum sudah semakin luas. Oleh karena itu, penegakan hukum tidak selalu sama untuk seluruh bidang hukum. Penegakan hukum pada suatu bidang hukum tertentu tidak selalu dapat serta merta digunakan pada bidang hukum yang lain. Dengan demikian dapat dikatakan pula bahwa keberhasilan penegakan hukum pada suatu bidang hukum belum tentu berhasil juga pada bidang hukum yang lain.

Hukum KI dapat ditakan termasuk bidang hukum yang berkembang cepat bahkan sangat cepat dibandingkan dengan bidang-bidang hukum yang lain. Perkembangan yang

\footnotetext{
${ }^{1}$ Hasima, H. Y. (2018, March), Perlindungan Hukum Hak Kekayaan Intelektual Masyarakat Kota Baubau. Halu Oleo Law Review, Volume 2(Issue 1), 335-353, hal.351.

${ }^{2}$ Sanyoto. (2008, September), PENEGAKAN HUKUM DI INDONESIA. Jurnal Dinamika Hukum, Volume 8(No.3), 199204, hal.199.

Penegakan Hukum Sebagai Upaya Meningkatkan Pendaftaran Dan Pencatatan Kekayaan Intelektual Di 
Jurnal Magister Hukum Program Pascasarjana Universitas HKBP Nommensen

Volume o1 Nomor o1 Juli 2020 Halaman. 113-128

e-ISSN: 2723-164X p-ISSN: 2722-9858

http://ejournal.uhn.ac.id/index.php/opinion

cepat inipun ternyata belum berhasil mengimbangi perkembangan KI yang memang berkembang sangat cepat. Tidak heran jika masalah-masalah di seputar KI masih banyak yang belum dapat diselesaikan dengan Hukum KI. Menurut Hikmahanto Juwana, Problem dalam penegakan hukum meliputi hal:

1. Problem pembuatan peraturan perundangundangan.

2. Masyarakat pencari kemenangan bukan keadilan.

3. Uang mewarnai penegakan hukum.

4. Penegakan hukum sebagai komoditas politik,

5. Penegakan hukum yang diskriminatif dan ewuh pekewuh.

6. Lemahnya sumberdaya manusia.

7. Advokat tahu hukum versus advokat tahu koneksi.

8. Keterbatasan anggaran.

9. Penegakan hukum yang dipicu oleh media masa. ${ }^{3}$

Penegakan hukum merupakan isu yang menarik untuk diteliti karena berkaitan dengan implementasi peraturan perundang-undangan yang berlaku. ${ }^{4}$ Adsapun esensi penegakan hukum adalah keadilan. ${ }^{5}$ Dengan kata lain penegakan hukum merupakan upaya untuk mewujudkan keadilan bagi masyarakat.

Menurut M Hawin \& Budi Agus Riswandi ${ }^{6}$ ada beberapa isu penting Kekayaan Intelektual di Indonesia, yaitu: Isu tentang moral, isu tentang impor paralel, perlindungan pengetahuan tradisional dan ekspresi budaya tradisional, pembatasan dan pengecualian Hak Cipta yang terkait dengan kepentingan publik di bidang pendidikan, pengaturan Collective Management Organization (CMO) atau Lembaga Manajemen Kolektif, serta jaminan fiducia Hak Cipta.

Salah satu kendala dalam memperoleh hak kekayaan intelektual adalah ketidaktahuan para penemu/pengrajin, atau pencipta atas proses pencatatan atau pendaftaran untuk mendapatkan hak di Dirjen HKI. Oleh karena itu, pemerintah harus mengambil inisiatif untuk memberikan pengetahuan tentang pencatatan atau pendaftaran HKI melalui pelatihan- pelatihan pendaftaran dan pendaftaran HKI dengan melibatkan pihak- pihak terkait seperti Perguruan Tinggi, Sentra HKI, LBH dan lain- lain. ${ }^{7}$

Sehubungan dengan masih banyak permasalahan di bidang KI dan Hukum KI terutama mengenai pendaftaran dan pencatatan KI serta penegakan hukum maka kami tertarik untuk melakukan penelitian dengan judul: "Penegakan Hukum Sebagai Upaya Meningkatkan Pendaftaran dan Pencatatan Kekayaan Intelektual di Indonesia.“ Rumusan masalah yang hendak dikaji adalah: Mengapa pendaftaran dan pencatatan Kekayaan Intelektual di Indonesia masih rendah? Bagaimanakah meningkatkan pendaftaran dan pencatatan Kekayaan Intelektual di Indonesia? Adapun tujuan penelitian ini adalah: Untuk mengetahui penyebab pendaftaran dan pencatatan Kekayaan Intelektual di Indonesia masih rendah serta upaya-upaya yang dapat dilakukan untuk meningkatkan

\footnotetext{
${ }^{3}$ Sanyoto. hal.199.

${ }^{4}$ Suwari Akhmaddhian, S. (2016, Januari o1), PENEGAKAN HUKUM LINGKUNGAN DAN PENGARUHNYA TERHADAP PERTUMBUHAN EKONOMI DI INDONESIA (Studi Kebakaran Hutan Tahun 2015). UNIFIKASI: Jurnal Ilmu Hukum, Vol. 03 ( o1), hal. 2.

${ }^{5}$ Susilo, A. (2018), Penegakan Hukum Yang Berkeadilan Dalam Perspektif Filsafat Hermeneutika Hukum. Jurnal Hukum dan Peradilan, 449-470.

${ }^{6}$ Riswandi, M. H. (2017), Isu-Isu Penting Hak Kekayaan Intelektual di Indonesia. Yogyakarta: Gadjah Mada University Press.

${ }^{7}$ Haris Yusuf \& Rahman Hasima, Perlindungan Hukum Hak Kekayaan Intelektual Masyarakat Kota Baubau, HOLREV (Halu Oleo Law Review), Volume 2 Issue 1, March 2018, hal. 351.
} 
Jurnal Magister Hukum Program Pascasarjana Universitas HKBP Nommensen

Volume o1 Nomor o1 Juli 2020 Halaman. 113-128

e-ISSN: 2723-164X p-ISSN: 2722-9858

http://ejournal.uhn.ac.id/index.php/opinion

pendaftaran dan pencatatan Kekayaan Intelektual di Indonesia. Hasil penelitan ini diharapkan akan dapat dimanfaatkan secara teoritis maupun praktis. Secara teoritis hasil penelitian ini diharapkan akan memperkaya teori-teori yang sudah ada di bidang KI. Secara praktis hasil penelitian ini diharapkan akan dapat dimanfaatkan secara langsung untuk meningkatkan pendaftaran dan pencatatan KI di Indonesia.

\section{B. Metode Penelitian}

Penelitian ini hendak mengetahui penyebab pendaftaran dan pencatatan KI di Indonesia masih rendah, Sehubungan dengan itu maka data yang diperlukan tidak hanya data sekunder melainkan data primer juga. Oleh karena itu, dalam penelitian ini akan digunakan metode penelitian hukum normatif dan sosiologis secara bersama-sama untuk dapat saling melengkapi satu sama lain.

Bahan hukum yang akan digunakan dalam penelitian ini mencakup bahan hukum primer, sekumder, maupun tersier. Penelitian tidak hanya akan dilakukan terhadapa peraturan perundang-undangan yang berlaku melainkan buku-buku dan bahan hukum lain mengenai KI.

Studi kepustakaan merupakan salah satu cara yang akan digunakan untuk mengumpulkan berbagai bahan hukum tersebut. Dalam hal perpustaan yang dimaksud tidak terbatas kepada perpustakaan dalam pengertian tempat karena pada saat ini sudah semakin banyak bahan pustaka yang tersimpan secara digital sehingga dapat diperoleh melalui teknologi informasi secara lebih leluasa. Studi kepustakaan ini akan disertai dengan wawancara dan observasi untuk memperoleh data primer.

Dikaitkan dengan masalah yang hendak diteliti maka pendekatan yang sesuai adalah pendekatan kasus dan pendekatan Undang-Undang. Pendekatan kasus (case approach) dilakukan dengan mengkaji kasus-kasus yang berkaitan dengan KI. Sementara itu, pendekatan Undang-undang (statute approah) yang dilakukan dengan mengkaji berbagai peraturan perundang-undangan tentang KI.

Sebagaimana telah disampaikan di atas penelitian ini akan menggunakan data primer maupun sekunder secara bersama-sama. Berdasarkan hal tersebut maka analisis akan dilakukan secara kualitatif maupun kuantitatif. Melalui analisis secara bersamasama semacam ini diharapkan akan diperoleh hasil penelitian yang baik sehingga dapat dimanfaatkan secara teoritis maupun praktis.

\section{Pembahasan}

\section{a. Penegakan Hukum}

Istilah penegakan hukum merupakan istilah yang sering dipergunakan di kalangan hukum bahkan dipergunakan masyarakat secara luas. Akan tetapi, dalam kenyataannya tidak jarang sesuatu istilah mempunyai pengertian yang berbeda antara kalangan hukum dengan masyarakat bahkan di antara kalangan hukum sendiri. Sehubungan dengan kenyataan itu akan dikemukakan beberapa pendapat mengenai penegakan hukum.

Menurut Satjipto Rahardjo, penegakan hukum pada hakikatnya merupakan penegakan ide-ide atau konsep-konsep yang abstrak. Penegakan hukum adalah usaha untuk mewujudkan ide-ide tersebut menjadi kenyataan. ${ }^{8}$ Berdasarkan pendapat ini maka penegakan hukum tidak selalu berkenaan dengan pelanggaran hukum melainkan

\footnotetext{
${ }^{8}$ H.R, Ridwan. (2016), Hukum Administrasi Negara. Jakarta: RajaGrafindo Persada, hal. 292. 
Jurnal Magister Hukum Program Pascasarjana Universitas HKBP Nommensen

Volume o1 Nomor o1 Juli 2020 Halaman. 113-128

e-ISSN: 2723-164X p-ISSN: 2722-9858

http://ejournal.uhn.ac.id/index.php/opinion

keseluruhan penegakan ide atau konsep hukum yang abstak.

Soerjono Soekanto mengatakan bahwa penegakan hukum adalah kegiatan menyerasikan hubungan nilai-nilai yang terjabarkan di dalam kaidah-kaidah/pendanganpandangan nilai yang mantap dan mengejawantah dan sikap tindak sebagai rangkaian penjabaran nilai tahap akhir untuk menciptakan (sebagai "social engineering"), memelihara dan mempertahankan (sebagai "social control") kedamaian pergaulan hidup. ${ }^{9}$ Berdasarkan pendapat ini penegakan hukum merupakan kegiatan dalam rangka menciptakan, memelihara dan mempertahankan kedamaian pergaulan hidup. Kegiatan semacam ini tidak cukup hanya dilakukan oleh aparat penegak hukum melainkan harus dilakukan bersama-sama oleh segenap masyarakat.

Hikmahanto Juwana menyatakan di Indonesia secara tradisional institusi hukum yang melakukan penegakan hukum adalah kepolisian, kejaksaan, badan peradilan dan advokat. ${ }^{10}$ Pernyataan secara tradisional mengindikasikan ada institusi lain yang melakukan penegakan hukum. Pernyataan ini nampak menekankan penegakan hukum pidana. Padahal penegakan hukum tidak hanya dalam bidang hukum pidana melainkan dalam keseluruhan bidang hukum. Dalam bidang hukum yang lain tentu saja tidak hanya kepolisian, kejaksaan, badan peradilan, dan advokat yang berperan sebagai penegak hukum.

Jika hakikat penegakan hukum itu mewujudkan nilai-nilai atau kaidah-kaidah yang memuat keadilan dan kebenaran maka penegakan hukum bukan hanya menjadi tugas dari para penegak hukum yang sudah dikenal secara konvensional. Akan tetapi, menjadi tugas dari setiap orang. ${ }^{11}$ Akan tetapi peran pemerintah tentu saja lebih besar daripada pihak-pihak lain. Mengenai hal ini J.B.J.M ten Berge mengatakan bahwa pihak pemerintahlah yang paling bertanggungjawab melakukan penegakan hukum, "De overheid is primair verantwoordelijk voor de handhaving van publiekrecht. ${ }^{\text {"12 }}$

Berdasarkan beberapa pendapat yang telah disampaikan dapat dikatakan pelaksanaan hukum di dalam masyarakat selain tergantung pada kesadaran hukum masyarakat juga sangat banyak ditentukan oleh aparat penegak hukum, Oleh karena sering terjadi beberapa peraturan hukum tidak dapat terlaksana dengan baik oleh karena ada beberapa oknum penegak hukum yang tidak melaksanakan suatu ketentuan hukum sebagaimana mestinya. ${ }^{13}$ Menurut Soerjono Soekanto ada lima faktor yang memengaruhi penegakan hukum, yaitu:

1. Faktor hukumnya sendiri;

2. Faktor penegak hukum, yaitu pihak-pihak yang membentuk maupun yang menerapkan hukum;

3. Faktor sarana atau fasilitas yang mendukung penegakan hukum;

4. Faktor masyarakat, yakni lingkungan dimana hukum tersebut berlaku atau diterapkan;

5. Faktor kebudayaan, yakni sebagai hasil karya, cipta, dan rasa yang didasarkan pada karsa manusia di dalam pergaulan hidup. (HR, 2016, hal. 293) ${ }^{14}$

Sementara itu J.B.J.M ten Berge menyebutkan beberapa aspek yang harus diperhatikan

\footnotetext{
${ }^{9}$ H.R, Ridwan. hal. 292.

${ }^{10}$ Sanyoto. hal.199.

${ }^{11}$ H.R, Ridwan. hal. 292.

${ }^{12}$ H.R, Ridwan. hal. 292.

${ }^{13}$ Sanyoto. hal.20o.

${ }^{14}$ H.R, Ridwan. hal.292.

Penegakan Hukum Sebagai Upaya Meningkatkan Pendaftaran Dan Pencatatan Kekayaan Intelektual Di Indonesia
} 
Jurnal Magister Hukum Program Pascasarjana Universitas HKBP Nommensen

Volume o1 Nomor o1 Juli 2020 Halaman. 113-128

e-ISSN: 2723-164X p-ISSN: 2722-9858

http://ejournal.uhn.ac.id/index.php/opinion

atau dipertimbangkan dalam rangka penegakan hukum, yaitu:

a. suatu peraturan harus sedikit mungkin membiarkan ruang bagi perbedaan interpretasi.

b. Ketentuan perkecualian harus dibatasi secara minimal.

c. Peraturan harus sebanyak mungkin diarahkan pada kenyataan yang secara objektif dapat ditentukan.

d. Peraturan harus dapat dilaksanakan oleh mereka yang terkena peraturan itu dan mereka yang dibebani dengan (tugas) penegakan (hukum). ${ }^{15}$

Dalam perbincangan mengenai penegakan hukum ini patut diperhatikan pendapat dari kalangan hukum progresif. Hukum progresif merupakan konsepsi yang menjalankan hukum tidak sekedar menurut perundang-undangan, tetapi alat untuk menjabarkan dasar kemanusiaan yang berfungsi memberikan keadilan kepada dunia dan manusia. Asumsi yang mendasari progresifisme hukum adalah pertama, hukum ada untuk manusia dan tidak untuk dirinya sendiri, kedua hukum selalu berada pada status law in the making dan tidak bersifat final, ketiga hukum adalah institusi yang bermoral kemanusiaan.

Ide utama dari hukum progresif adalah membebaskan manusia dari belenggu hukum. Menurut hukum progresif, hukum berfungsi memberi panduan bukan justru membelenggu, manusia-manusialah yang lebih penting dan tidak terpaku pada peraturan perundang-undangan yang ada. Sedangakan menurut hukum positif, norma hukum yang ditetapkan itu tidak lain adalah Undang-undang, dan teori hukum positif mengakui adanya norma hukum yang bertentangan dengan nilai moral. ${ }^{16}$

Keberagaman pendapat mengenai pengertian penegakan hukum saja sudah merupakan seuatu yang menarik untuk diteliti. Selain itu, penegakan hukum merupakan isu yang menarik untuk diteliti karena berkaitan dengan implementasi peraturan perundang-undangan yang berlaku. ${ }^{17}$ Implementasi peraturan perundsang-undangan tidak hanya bergantung kepada pihak tertentu atau pihak-pihak tertentu seperti aparat penegak hukum melainkan bergantung kepada keterlibatan seluruh lapisan masyarakat. Oleh karena itu, tanpa penegakan hukum percuma saja ada peraturan perundangundangan. Adapun esensi penegakan hukum adalah keadilan. ${ }^{18}$ Oleh karena itu, dapatkan dikatakan bahwa penegakan hukum merupakan upaya untuk mewujudkan keadilan. Tanpa penegakan hukum maka keadilan tidak akan dapat diwujudkan.

\section{b. Pendaftaran dan Pencatatan Kekayaan Intelektual}

Ketika membahas mengenai Hak Cipta Kollewijn ${ }^{19}$ menyatakan ada dua cara atau stelsel pendaftaran, yaitu stelsel konstitutif dan steksel deklaratif. Yang pertama, berarti bahwa hak atas ciptaan baru terbit karena pendaftaran yang telah mempunyai kekuatan. Yang kedua ialah bahwa pendaftaran itu bukanlah menerbitkan hak melainkan hanya memberikan dugaan atau sangkaan saja menurut undang-undang bahwa orang yang hak ciptaannya terdaftar itu adalah si berhak sebenarnya sebagai pencipta dari hak yang didaftarkannya. Sehubungan dengan hal inilah istilah yang digunakan untuk Hak Cipta bukan lagi pendaftaran melainkan menjadi pencatatan.

\footnotetext{
${ }^{15}$ H.R, Ridwan. hal. 295 .

${ }^{16}$ Setiaji, M. \&. (2018, November), Kajian Hak Asasi Manusia dalam Negara The Rule of Law: Antara Hukum Progresif dan Hukum Positif. Lex Scientia Law Review, Volume 2(No.2), 123-138, hal. 136.

${ }^{17}$ Suwai Akhmaddhian. hal. 2.

${ }^{18}$ Susilo, A. (2018), Penegakan Hukum Yang Berkeadilan Dalam Perspektif Filsafat Hermeneutika Hukum. Jurnal Hukum dan Peradilan, 449-470.

${ }^{19}$ O.K Saidin. (2015). ASPEK HUKUM HAK KEKAYAAN INTELEKTUAL (Intellectual Property Rights). Jakarta: Rajawali Pers, hal. 242.

Penegakan Hukum Sebagai Upaya Meningkatkan Pendaftaran Dan Pencatatan Kekayaan Intelektual Di 
Jurnal Magister Hukum Program Pascasarjana Universitas HKBP Nommensen

Volume o1 Nomor o1 Juli 2020 Halaman. 113-128

e-ISSN: 2723-164X p-ISSN: 2722-9858

http://ejournal.uhn.ac.id/index.php/opinion

Dalam Undang-Undang tenang Hak Cipta disebutkan bahwa kecuali terbukti sebaliknya, yang dianggap sebagai Pencipta, yaitu Orang yang namanya: disebut dalam Ciptaan; dinyatakan sebagai Pencipta pada suatu Ciptaan; disebutkan dalam surat pencatatan Ciptaan; dan/atau tercantum dalam daftar umum Ciptaan sebagai Pencipta. Dengan demikian pencatatan merupakan hal penting dalam Hak Cipta terkhusus dalam rangka pembuktian sebagai Pencipta.

Ada dua sistem pendaftaran paten yang dikenal di dunia, yaitu: sistem registrasi dan sistem ujian. ${ }^{20}$ Berdasarkan sistem registrasi setiap permohonan pendaftaran paten diberi paten oleh kantor paten secara otomatis. Spesifikasi dari permohonan paten hanya memuat uraian dan monopoli yang diminta tanpa penjelasan secara rinci. Sementara itu berdasarkan sistem ujian setiap permohonan paten akan diuji dulu. Ada tiga unsur atau kriteria yang diuji, yaitu: Invensi harus memenuhi syarat-syarat untuk diberi hak atas paten menurut undang-undang paten, invensi harus mengadung sifat kebaruan, invensi harus mengandung unsur menemukan sesuatu yang bersifat kemajuan (invention step) dari apa yang diketahui.

Secara internasional dikenal empat sistem pendaftaran merek ${ }^{21}$, yaitu: Pendaftaran merek tanpa pemeriksaan merek terlebih dahulu, pendaftaran dengan pemeriksaan merek terlebih dahulu, pendaftaran dengan pengumuman sementara, dan pendaftaran merek dengan pemberitahuan terlebih dahulu tentang adanya merek-merek terdaftar lain yang ada persamaannya.

Demikianlah uraian mengenai pengertian pendaftaran dan pencatatatan dalam Hak Cipta, Paten, dan Merek. Pengertian ini berlaku juga untuk Kekayaan Intelektual yang lain dengan kemungkinan ada beberapa kekhususan untuk masing-masing KI dan kekhususan di setiap negara serta peraturan perundang-undangan.

Berdasarkan uraian mengenai pendaftaran dan pencatatan yang telah disampaikan dapat diketahui bahwa pendaftaran dan pencatatan merupakan sebagian dari penegakan hukum. Pendafataran dan pencatatan merupakan upaya untuk memberikan keadilan bagi masyarakat terutama bagi anggota masyarakat yang telah bersusah payah menghasilkan Kekayaan Intelektual.

\section{c. Penegakan Hukum Kekayaan Inteletual di Indonesia}

Dalam bab yang lalu telah disampaikan bahwa penegakan hukum sering dikaitkan dengan pelanggaran hukum terutama Hukum Pidana meskipun sesungguhnya tidak selalu begitu. Kenyaan ini misalnya dapat dilihat ketika memperbincangkan mengenai Merek. Permasalahan Hak Kekayaan Intelektual khususnya bidang merek merupakan suatu permasalahan yang terus akan berkembang mengikuti perkembangan dunia ilmu pengetahuan. Hal tersebut dapat terlihat dari semakin maraknya kejahatan salah satunya dalam sektor perdagangan yang terjadi saat ini. Modus daripada kejahatan tersebut salah satunya adalah pelanggaran terhadap suatu merek terkenal yang di eksploitasi menjadi suatu komiditi untuk mendapatkan keuntungan. ${ }^{22}$

Kenyataan yang tidak jauh berbeda terjadi ketika memperbincangkan mengenai Hak Cipta. Dalam prosiding tentang HaKI dari Lokakarya terbatas masalah Kepailitan dan wawasan Hukum Bisnis lainnya dieditori Emmy Yuhassarie dinyatakan bahwa faktor-

\footnotetext{
${ }^{20}$ O.K Saidin. hal. 257.

${ }^{21}$ O.K Saidin. hal. 473 .

${ }^{22}$ Nourma Dewi \& Tunjung Baskoro, KASUS SENGKETA MEREK PRADA S.A DENGAN PT. MANGGALA PUTRA PERKASA DALAM HUKUM PERDATA INTERNASIONAL. Jurnal Ius Constituendum | Volume 4 Nomor 1 April 2019, hal. 21.
}

Penegakan Hukum Sebagai Upaya Meningkatkan Pendaftaran Dan Pencatatan Kekayaan Intelektual Di Indonesia 
Jurnal Magister Hukum Program Pascasarjana Universitas HKBP Nommensen

Volume o1 Nomor o1 Juli 2020 Halaman. 113-128

e-ISSN: 2723-164X p-ISSN: 2722-9858

http://ejournal.uhn.ac.id/index.php/opinion

faktor yang mempengaruhi maraknya pembajakan karya cipta adalah: (1) faktor sosial ekonomi, (2) faktor sosial budaya, (3) perbandingan harga, (4) pendidikan, (5) rendahnya sanksi hukum.

Berikut ini macam-macam tindak pidana dalam berbagai peraturan perundang-undangan tentang KI di Indonesia.

1. Undang-Undang Nomor 13 Tahun 2016 tentang Paten:

a. Tindak pidana dalam hal paten produk sengaja dan tanpa hak membuat, menggunakan, menjual, mengimpor, menyewakan, menyerahkan, atau menyediakan untuk dijual atau disewakan atau diserahkan produk yang diberi Paten. (Pasal 161 jo Pasal 16o huruf a.

b. Tindak pidana dalam hal Paten proses sengaja dan tanpa hak menggunakan proses produksi yang diberi Paten untuk membuat barang dan tindakan lainnya. (Pasal 161 jo 160 huruf b).

c. Tindak pidana dalam hal Patem sederhana sengaja dan tanpa hak membuat, menggunakan, menjual, mengimpor, menyewakan, menyerahkan, atau menyediakan produk yang diberikan Paten sederhana. (Pasal 162 jo Pasal 160).

d. Tindak pidana sengaja dan tanpa hal membocorkan dokumen permohonan yang bersifat rahasia. (Pasal 164).

2. Undang-Undang Nomor 20 Tahun 2016 tentang Merek dan Indikasi Geografis:

a. Tindak pidana menggunakan Merek yang sama keseluruhannya dengan Merek terdaftar milik pihak lain untuk barang dan/atau jasa sejenis. (Pasal 100 ayat (1)).

b. Tindak pidana menggunakan Merek yang sama pada pokoknya dengan Merek terdaftar milik pihak lain untuk barang dan/atau jasa sejenis. (Pasal 100 ayat (2)).

c. Tindak pidana menggunakan tanda yang sama pada keseluruhan dengan Indikasi Geografis milik pihak lain. (Pasal 101 ayat (1)).

d. Tindak pidana menggunakan tanda yang sama pada pokoknya dengan Indikasi Geografis milik pihak lain. (Pasal 101 ayat (2)).

e. Tindak pidana memperdagangkan barang dan/atau jasa dan/atau produk yang diketahui atau diduga mengetahui bahwa barang dan/atau jasa dan/atau produk milik orang lain. (Pasal 102).

3. Undang-Undang Nomor 28 Tahun 2014 tentang Hak Cipta:

a. Tindak pidana tanpa hak menghilangkan, mengubah atau merusak informasi manajemen hak cipta dan informasi elektronik hak cipta yang dimiliki pencipta dan/atau merusak, memusnahkan, menghilangkan, atau membuat tidak berfungsi sarana kontrol teknologi yang digunakan sebagai pelindung ciptaan atau produk hak terkait serta pengaman hak cipta atau hak terkait. (Pasal 112 jo Pasal 7 ayat (3) dan/atau Pasal 52).

b. Tindak pidana tanpa hak (tanpa izin pencipta atau pemegang hak cipta) melakukan pelanggaran hak ekonomi mengenai penyewaan hak ciptaan untuk penggunaan secara komersial. (Pasal 113 ayat (1) jo Pasal 9 ayat (1) huruf i).

c. Tindak pidana tanpa hak dan/atau tanpa izin pencipta atau pemegang hak cipta melakukan pelanggaran hak ekonomi pencipta mengenai penerjemahan hak cipta, pengadaptasian, pengaransemenan, pentransformasian ciptaan, pertunjukan ciptaan atau salinannya, komunikasi ciptaan untuk penggunaan secara komersial. (Pasal 113 ayat (2) jo Pasal 8 ayat (1) huruf c, huruf d, huruf f, dan/atau huruf h). 
Jurnal Magister Hukum Program Pascasarjana Universitas HKBP Nommensen

Volume o1 Nomor o1 Juli 2020 Halaman. 113-128

e-ISSN: 2723-164X p-ISSN: 2722-9858

http://ejournal.uhn.ac.id/index.php/opinion

d. Tindak pidana tanpa hak dan/atau tanpa izin pencipta atau pemegang hak cipta melakukan pelanggaran hak ekonomi pencipta mengenai penerbitan ciptaan, penggandaan ciptaan dalam segala bentuknya, pendistribusian ciptaan atau salinannya untuk penggunaan secara komersial. (Pasal 113 ayat (3) jo Pasal 9 ayat (1) huruf a, huruf b, huruf e, dan huruf g).

e. Tindak pidana tanpa hak dan/atau tanpa izin pencipta atau pemegang hak cipta melakukan pelanggaran hak ekonomi pencipta mengenai penerbitan ciptaan, penggandaan ciptaan dalam segala bentuknya, pendistribusian ciptaan atau salinannya untuk penggunaan secara komersial dalam bentuk pembajakan. (Pasal 113 ayat (4) jo Pasal 9 ayat (1) huruf a, hurub b, huruf e, dan huruf g).

f. Tindak pidana mengelola tempat perdagangan dalam segala bentuknya dengan sengaja dan mengetahui membiarkan penjualan dan/atau penggandaan barang hasil pelanggaran hak cipta dan/atau hak terkait di tempat perdagangan yang dikelolanya. (Pasal 114 jo Pasal 10).

g. Tindak pidana tanpa persetujuan dari orang yang dipotret atau ahli warisnya melakukan pelanggaran secara komersial, penggandaan, pengumuman, pendistribuasian atau komunikasi atas potret sebagaimana dimaksud dalam Pasal 12 untuk kepentingan reklame atau periklanan untuk penggunaan secara komersial baik dalam media elektronik maupun non elektronik. (Pasal 115 jo Pasal 12).

h. Tindak pidana tanpa hak melakukan pelanggaran hak ekonomi pelaku pertunjukan mengenai penyewaan atas fiksasi pertunjukan atau salinannya kepada publik secara komersial. (Pasal 116 ayat (1) jo Pasal 23 ayat (2) huruf e).

i. Tindak pidana tanpa hak melakukan pelanggaran hak ekonomi pelaku pertunjukan yang meliputi hak melaksanakan sendiri, memberikan izin, atau melarang pihak lain untuk melakukan:

1. Penyiaran atau komunikasin atau pertunjukan pelaku pertunjukan.

2.Fiksasi dari pertunjukannya yang belum difiksasi dan/atau

3.Penyediaan atas fiksasi pertunjukan yang dapat diakses publik untuk penggunaan secara komersial. (Pasal 116 ayat (2) jo Pasal 23 huruf a, huruf b, dan huruf f).

j. Tindak pidana tanpa hak melakukan pelanggaran hak ekonomi pelaku pertunjukan meliputi hak melaksanakan sendiri, memberikan izin, atau melarang pihak lain untuk melakukan:

1. Penggunaan atas fiksasi pertunjukannya dengan cara atau bentuk apapun; 2.Pendistribusian atas fiksasi pertunjukan atau salinannya untuk penggunaan secara komersial (Pasal 116 ayat (3) jo Pasal 23 ayat (2) huruf c dan/atau huruf d).

k. Tindak pidana tanpa hak melakukan pelanggaran hak ekonomi pelaku pertunjukan meliputi hak melaksanakan sendiri, memberikan izin, atau melarang pihak lain untuk melakukan:

1. Penggunaan atau fiksasi pertunjukannya dengan cara atau bentuk apapun; 2.Pendistribusian atas fiksasi pertunjukan atau salinannya untuk penggunaan secara komersial dilakukan dalam bentuk pembajakan. (Pasal 116 ayat (4) jo Pasal 23 ayat (2) huruf c dan hurud d).

1. Tindak pidana dengan sengaja dan tanpa hak melakukan pelanggaran hak ekonomi produsen fonogram meliputi hak melaksanakan sendiri, memberikan izin,, atau melarang pihak lain untuk melakukan penyewaan kepada publik atas salinan 
Jurnal Magister Hukum Program Pascasarjana Universitas HKBP Nommensen

Volume o1 Nomor o1 Juli 2020 Halaman. 113-128

e-ISSN: 2723-164X p-ISSN: 2722-9858

http://ejournal.uhn.ac.id/index.php/opinion

fonogram untuk penggunaan secara komersial. (Pasal 117 ayat (1) jo Pasal 24 ayat

(2) huruf c).

m.Tindak pidana dengan sengaja dan tanpa hak melakukan pelanggaran hak ekonomi produser fonogram meliputi hak melaksanakan sendiri, memberikan izin, atau melarang pihak lain untuk melakukan penggandaan atas fonogram dengan cara atau bentuk apapun, pendistribusian atas fonogram asli atau salinannya. (Pasal 117 ayat (2) jo Pasl 24 huruf a dan b).

n. Tindak pidana dengan sengaja dan tanpa hak ekonomi produser fonogram meliputi hak melaksanakan sendiri, memberikan izin, atau melarang pihak lain untuk melakukan penyewaan kepada publik atas salinan fonogram untuk penggunaan secara komersial dilakukan dalam bentuk pembajakan. (Pasal 117 ayat (1) jo Pasal 24 ayat (2) huruf c).

o. Tindak pidana dengan sengaja dan tanpa hak melakukan pelanggaran hak ekonomi produser fonogram meliputi hak melaksanakan sendiri, memberikan izin, atau melarang pihak lian untuk melakukan penggandaan atas fonogram dengan cara atau bentuk apapun, pendistribusian atas fonogram asli atau salinannya yang dilakukan dalam bentuk pembajakan. (Pasal 117 ayat (3) jo 24 ayat (2) huruf a atau b).

p. Tindak pidana dengan sengaja dan tanpa hak melakukan pelanggaran hak ekonomi lembaga penyiasran yang meliputi hak melaksanakan sendiri, memberikan izin, atau melarang pihak lain untuk melakukan penyiaran ulang siaran, komunikasi siaran, fiksasi siaran, dan/atau penggandaan fiksasi siaran untuk penggunaan secara komersial. (Pasal 118 ayat (1) jo Pasal 25 ayat (2) huruf a, b, c, dan huruf c).

q. Tindak pidana dengan sengaja dan tanpa hak melakukan pelanggaran hak ekonomi lembaga penyiaran yanh meliputi hak melaksanakan sendiri, memberikan izin, atau melarang pihak lain untuk melakukan penyiaran ulang siaran, komunikasi siaran, fiksasi siaran, dan/atau penggandaan fiksasi siaran untuk penggunaan secara komersial dengan maksud pembajakan. (Pasal 118 ayat (2) jo Pasal 25 ayat (2) huruf a, b, c, dan d).

r. Tindak pidana lembaga manajemen kolektif yang tidak memiliki izin operasional dari Menteri melakukan kegiatan penarikan royalti. (Pasal 118 jo Pasal 88 ayat (3)).

4. Undang-Undang Nomor 29 Tahun 2000 tentang Perlindungan Varietas Tanaman:

a. Tindak pidana dengan sengaja memprodukasi atau memperbanyak benih, mengiklankan, menawarkan, dan lain-lain varietas tanaman tanpa persetujuan Pemegang Hak PVT. (Pasal 71 jo Pasal 6 ayat (3)).

b. Tindak pidana konsultas PVT sengaja tidak merahasiakan varietas tanaman dan dokumen permohonan Hak PVT. (Pasal 72 jo Pasal 13 ayat (1)).

c. Tindak pidana pegawai kantor PVT sengaja tidak merahasiakan varietas dan dokumen permohonan Hak PVT. (Pasal 52 jo Pasal 23).

d. Tindak pidana dengan sengaja dan untuk tujuan komersial menggunakan hasil panen dari varietas yang dilindungi. (Pasal 73 jo Pasal 10 ayat (1)).

e. Tindak pidana Pemeriksa PVT atau Pejabat yang terkait dengan pemeriksaan substantif dengan sengaja tidak menjaga kerahasiaan varietas yang diperiksanya. (Pasal 74 jo Pasal 30 ayat (3)).

5. Undang-Undang Nomor 30 Tahun 2000 tentang Rahasia Dagang: 
Jurnal Magister Hukum Program Pascasarjana Universitas HKBP Nommensen

Volume o1 Nomor o1 Juli 2020 Halaman. 113-128

e-ISSN: 2723-164X p-ISSN: 2722-9858

http://ejournal.uhn.ac.id/index.php/opinion

a. Tindak pidana dengan sengaja dan tanpa hak menggunakan Rahasia Dagang pihak lain. (Pasal 17 ayat (1).

b. Tindak pidana dengan sengaja dan tanpa hak mengungkapkan Rahasia Dagang, mengingkari kesepakatan atau mengingkari kewajiban menjaga rahasia dagang. (Pasal 17 ayat (1) jo Pasal 13).

c. Tindak pidana dengan sengaja memperoleh atau menguasasi Rahasia Dagang dengan cara yang bertentangan dengan peraturan perundang-undangan yang berlaku. (Pasal 17 ayat (1) jo Pasal 14).

6. Undang-Undang Nomor 31 Tahun 2000 tentang Desain Industri:

a. Tindak pidana dengan sengaja dan tanpa hak membuat, memakai, menjual, mengimpor, mengekspor, dan/atau mengedarkan barang yang diberi Hak Desain Industri. (Pasal 54 ayat (1) jo Pasal 9).

b. Tindak pidana dengan sengaja tidak mencantumkan nama Pendesain Hak Desain Industri dalam Sertifikat Desain Industri, Daftar Umum Desain Industri, dan Berita Resmi Desain Industri. (Pasal 54 ayat (2) jo Pasal 8).

c. Tindak pidana dengan sengaja melanggar kewajiban menjaga kerahasiaan permohonan sampai dengan diumumkannya permohonan Hak Desain Industri. (Pasal 54 ayat (2) jo Pasal 23).

d. Tindak pidana dalam hal pengalihan Hak Desain Industri dengan sengaja tidak lagi mencantumkan nama dan identitas Pendesain Desain Industri dalam Sertifikat Desain Industri, Berita Resmi Desain Industri, maupun dalam Daftar Umum Desain Industri. (Pasal 54 ayat (2) jo Pasal 32).

7. Undang-Undang Nomor 32 Tahun 2000 tentang Desain Tata Letak Sirkuit Terpadu (DTLST):

a. Tindak pidana sengaja dan tanpa hak membuat, memakai, menjual, mengimpor, mengekspor, dan/atau mengedarkan barang yang di dalamnya terdapat seluruh atau sebagian Desain yang telah diberik Hak DTLST. (Pasal 42 ayat (1) jo Pasal 8 ayat (1)).

b. Tindak pidana sengaja tidak mencantumkan nama Pendesain dalam Sertifikat DTLST, Daftar Umum DTLST, dan Berita Resmi DTLST. (Pasal 42 ayat (2) jo Pasal 7).

c. Tindak pidana pengawai Direktorat Jenderal atau orang yang karena tugasnya bekerja untuk dan/atau atas nama Direktorat Jenderal sengaja tidak menjaga kerahasiaan Permohonan. (Pasal 42 ayat (2) jo Pasal 19).

d. Tindak pidana dalam hal pengalihan Hak DTLST dengan sengaja tidak lagi mencantumkan nama dan identitas Pendesai DTLST dalam Sertifikat DTLST, Berita Resmi DTLST, dan Daftar Umum DTLST. (Pasal 42 ayat (2) jo Pasal 24).

Berkenaan dengan sanksi dapat disampaikan penjelasan sebagai berikut. Sanksi hukum yang diterapkan terhadap pembajakan hanya diterapkan pada penjual barang bajakan, belum diterapkan pada konsumen yang membeli barang bajakan. Selama ini penegakkan hukum di bidang hak Cipta belum berlaku secara menyeluruh. Apabila mengacu pada UUHC, maka sanksi yang ditekankan kepada pembajak hanya bersifat denda semata dan belum mengarah pada sanksi yang bersifat pemidaan. ${ }^{23}$ Penekanan terhadap Hukum Pidana tentu saja bukan tanpa alasan. Sampai sekarang masyarakat

\footnotetext{
${ }^{23}$ Nahrowi, N. (2014), PLAGIAT DAN PEMBAJAKAN KARYA CIPTA DALAM HAK KEKAYAAN INTELEKTUAL. SALAM: Jurnal Sosial Dan Budaya Syar-I, 1(2). https://doi.org/10.15408/sjsbs.vii2.1541, hal. 230 
Jurnal Magister Hukum Program Pascasarjana Universitas HKBP Nommensen

Volume o1 Nomor o1 Juli 2020 Halaman. 113-128

e-ISSN: 2723-164X p-ISSN: 2722-9858

http://ejournal.uhn.ac.id/index.php/opinion

masih lebih mengenal bidang hukum ini daripada bidang-bidang hukum yang lain ketika berbincang mengenai penegakan hukum. Istilah penegak hukum dapat dikatakan identik dengan penegak hukum pidana.

Dalam berbagai peraturan perundang-undangan, terutama Undang-Undang di bidang KI, ditemukan juga sanksi selain sanksi pidana seperti sanksi administrasi berupa pembatalan dan pencabutan. Sebagai contoh dalam Undang-Undang Nomor 29 Tahun 2000 tentang Perlindungan Varietas Tanaman disebutkan Hak PVT berakhir karena berakhirnya jangka waktu, pembatalan, dan pencabutan.

Pembatalan hak PVT dilakukan oleh Kantor PVT. Hak PVT dibatalkan apabila setelah hak diberikan ternyata syarat-syarat kebaruan dan/atau keunikan tidak dipenuhi pada saat pemberian hak PVT, syarat-syarat keseragaman dan/atau stabilitas sebagaimana dimaksud tidak dipenuhi pada saat pemberian hak PVT, atau hak PVT telah diberikan kepada pihak yang tidak berhak.

Pencabutan hak PVT dilakukan oleh Kantor PVT. Hak PVT dicabut berdasarkan alasan: pemegang hak PVT tidak memenuhi kewajiban membayar biaya tahunan dalam jangka waktu enam bulan; syarat/ciri-ciri dari varietas yang dilindungi sudah berubah atau tidak sesuai lagi dengan ketentuan, pemegang hak PVT tidak mampu menyediakan dan menyiapkan contoh benih varietas yang telah mendapatkan hak PVT, pemegang hak PVT tidak menyediakan benih varietas yang telah mendapatkan hak PVT, atau pemegang hak PVT mengajukan permohonan pencabutan hak PVT-nya, serta alasannya secara tertulis kepada Kantor PVT.

Faktor-faktor yang menyebabkan keadilan sulit untuk di tegakkan di negara Indonesia ditinjau dari filsafat hermeneutik dan filsafat ilmu hukum adalah faktor yang bersifat fundamental, yakni : salahnya sistem pendidikan hukum yang melulu mengajarkan pola pikir yuridis-normatif (bahkan presentase pengajarannya lebih dari 8o $\%$ berkisar sistem dan filsafat hukum yang positivistik). Faktor lainnya adalah kurangnya pendidikan karakter bangsa Indonesia dan masih lemahnya pelaksanaan moral dalam penegakan hukum. Dan yang terakhir kurang di dukungnya konsep hukum non-doktrinal oleh banyak akademisi (ilmuwan) dan praktisi hukum di Indonesia, karena pandangan positivistiknya sudah mendarah daging bersemayam dalam pikirannya. ${ }^{24}$

Dari uraian tersebut dapat disimpulkan, bahwa tanpa kepastian orang tidak tahu apa yang harus diperbuatnya dan akhirnya timbul keresahan. Tetapi apabila kita terlalu mengejar kepastian hukum, terlalu ketat dalam mentaati peraturan hukum akibatnya akan menjadi kaku dan akan menimbulkan rasa tidak adil. Kalau dalam penegakan hukum hanya memperhatikan kepastian hukum, maka unsur-unsur lainnya akan dikorbankan. Demikian pula kalau yang diperhatikan hanyalah kemanfaatan, maka kepastian hukum dan keadilan dikorbankan, demikian seterusnya. Oleh karena itu dalam penegakan hukum lingkungan ketiga unsur tersebut, yaitu kepastian, kemanfaatan dan keadilan harus dikompromikan. Artinya ketiganya harus mendapat perhatian secara proposional seimbang dalam penanganannya, meskipun dalam praktek tidak selalu mudah melakukannya. ${ }^{25}$

\footnotetext{
${ }^{24}$ Agus Budi Susilo, PENEGAKAN HUKUM YANG BERKEADILAN DALAM PERSPEKTIF FILSAFAT HERMENEUTIKA HUKUM (Suatu Solusi Terhadap Problematika Penegakan Hukum Di Indonesia). Jurnal Hukum dan Peradilan, Volume 2 Nomor 3 November 2013 ISSN : 2303-3274, hal.467.

${ }^{25}$ Suwari Akhmaddhian, PENEGAKAN HUKUM LINGKUNGAN DAN PENGARUHNYA TERHADAP PERTUMBUHAN EKONOMI DI INDONESIA (Studi Kebakaran Hutan Tahun 2015), Jurnal Unifikasi. ISSN 2354-5976 Vol. o3 Nomor o1 Januari 2016, hal 15-16.
}

Penegakan Hukum Sebagai Upaya Meningkatkan Pendaftaran Dan Pencatatan Kekayaan Intelektual Di Indonesia 
Jurnal Magister Hukum Program Pascasarjana Universitas HKBP Nommensen

Volume o1 Nomor o1 Juli 2020 Halaman. 113-128

e-ISSN: 2723-164X p-ISSN: 2722-9858

http://ejournal.uhn.ac.id/index.php/opinion

Perlu melakukan pembenahan institusi Pengadilan Niaga, khususnya kepada aparatur penegak hukum dalam hal ini Hakim pada Pengadilan Niaga sebagai Pengadilan yang mempunyai kompetensi penyelesaian sengketa hak kekayaan intelektual untuk lebih dapat meningkatkan kualitas sumber daya manusia dari para hakim itu sendiri, sehingga diharapkan pembenahan sistem Pengadilan Niaga ini nantinya akan meningkatkan mutu atau kualitas putusan pengadilan terhadap sengketa hukum merek yang mampu menjawab rasa keadilan dan memunculkan hakim-hakim yang profesional dan tentunya memberikan hasil yang maksimal pada putusannya. ${ }^{26}$

\section{d. Pendaftaran dan Pencatatan Kekayaan Intelektual di Indonesia}

Berdasarkan publikasi yang dilakukan Direktorat Jenderal KI melalui website nya dapat diketahui bahwa permohonan mengalami peningkatan dari tahun ke tahun.

Peningkatan permohonan itu tentu saja akan berbanding lurus dengan peningkatan pendaftaran dan pencatatan Kekayaan Intelektual.

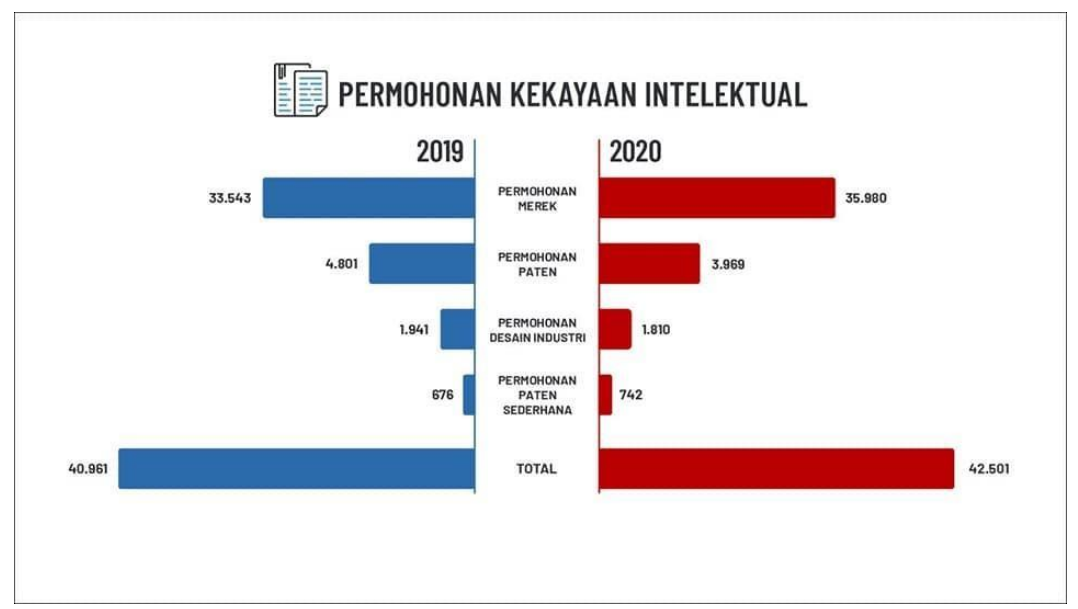

Peningkatan pendafataran dan pencatatan KI sangat mungkin dipengaruhi penegakan hukum yang semakin baik sehingga masyarakat semakin bersemangat untuk mendaftarkan dan/atau mencatatkan KI mereka. Akan tetapi peningkatan pendaftaran dan pencatatan tidak harus diiringi dengan peningkatan permasalahan terlebih sengketa di bidang ini melainkan sebaliknya.

Berikut ini disampaikan data pengaduan ke Direktorat Jenderal Kekayaan Intelektual Kementerian Hukum dan Hak Asasi Manusia selama enam bulan pada pada tahun 2019 (Januari sampai Juni).

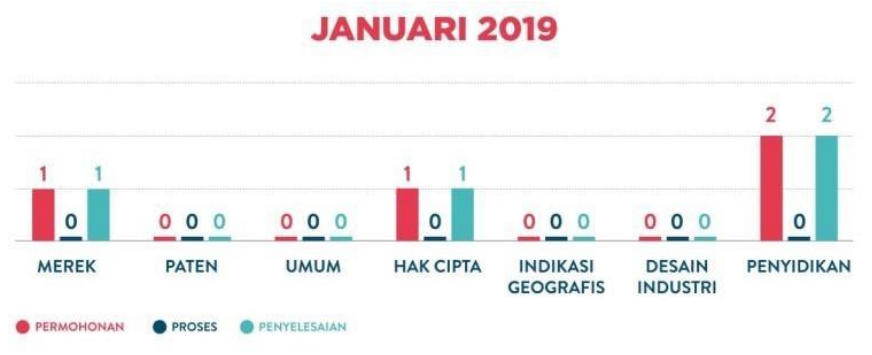

\footnotetext{
${ }^{26}$ Adhi Budi Susilo, PENYELESAIAN SENGKETA PEMBATALAN PENDAFTARAN MEREK (STUDI KASUS DUA KELINCI DAN GARUDA FOOD), Jurnal Law reform - April 2011 Vol. 6 No.1 141.
} 
FEBRUARI 2019

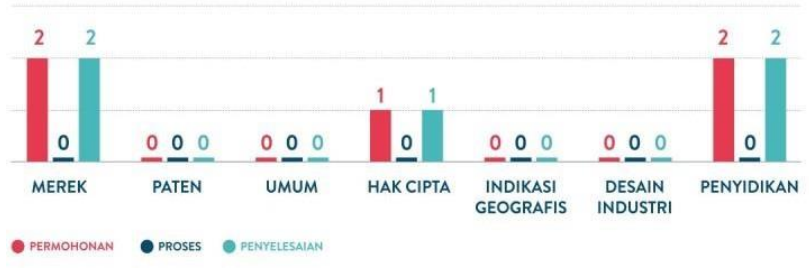

MARET 2019

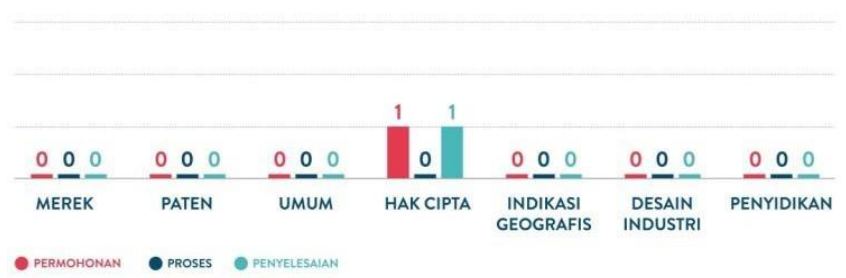

APRIL 2019
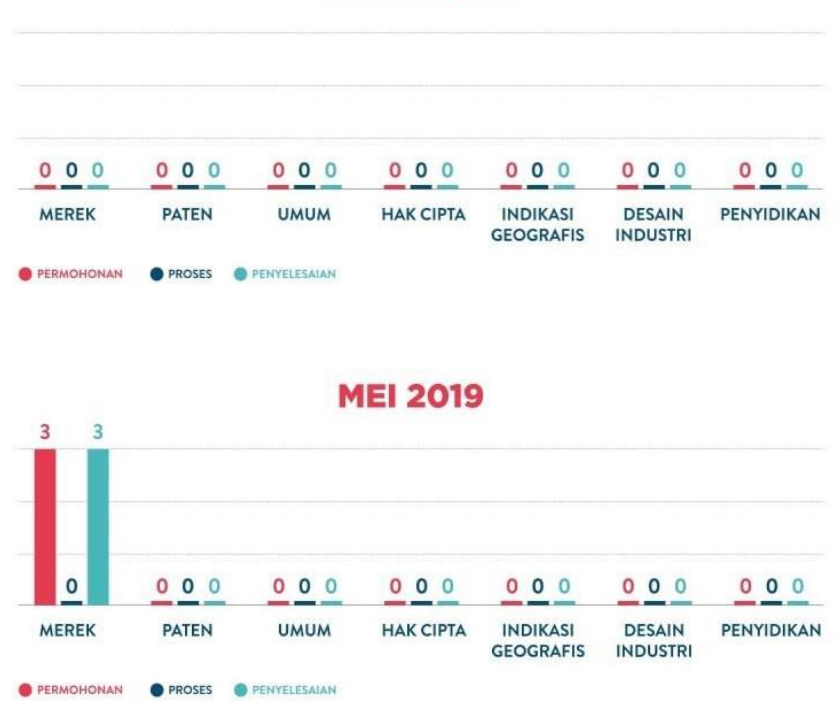

JUNI 2019

Berdasarkan data di atas dapat diketahui bahwa pengaduan berkaitan dengan KI terutama Merek, Paten, Hak Cipta, Indikasi Geografis, dan Desain Industri ke Direktoral Jenderal Kekayaan Intelektual belum banyak tetapi sudah mulai ada. Kenyataan bahwa tidak banyak pengaduan dapat mengidikasikan penegakan hukum yang sudah baik tetapi tidak tertutup kemungkinan lain seperti masyarakat merasa kurang bermanfaat 
Jurnal Magister Hukum Program Pascasarjana Universitas HKBP Nommensen

Volume o1 Nomor o1 Juli 2020 Halaman. 113-128

e-ISSN: 2723-164X p-ISSN: 2722-9858

http://ejournal.uhn.ac.id/index.php/opinion

melakukan pengaduan. Dari data di atas dapat diketahui bahwa semua pengaduan dapat diselesaikan. Mengenai hal ini patut diapresiasi Direktoral Jenderal Kekayaan Intelektual.

\section{Kesimpulan}

Berdasarkan uraian yang telah disampaikan dapat ditarik kesimpulan sebagai berikut.

1. Pendaftaran dan pencatatan Kekayaan Intelektual di Indonesia masih rendah karena masyarakat belum mengetahui banyak mengenai seluk beluk pendafataran dan pencatatan. Selain itu, masyarakat merasa percuma melakukan pendafataran dan pencatatan karena penegakan hukum KI masih rendah seperti masih belum tegas penegakan hukum dalam hal terjadi pembajakan atas KI.

2. Ada beberbagai upaya yang sudah dilakukan untuk meningkatkan pendaftaran dan pencatatan Kekayaan Intelektual di Indonesia, antara lain melalui penegakan hukum KI yang semakin baik serta pendafataran dan pencatatan KI yang semakin mudah dan semakin murah.

Berkaitan dengan kesimpulan di atas perkenankan menyampaikan saran sebagai berikut:

1. Perlu dibuat peraturan tentang keharusan memasukkan materi Kekayaan Intelektual di semua program studi di Perguruan Tinggi bahkan sejak sekolah Dasar dan Menengah, baik berupa mata kuliah tersendiri maupun masuk dalam materi mata kuliah tertentu.

2. Perlu upaya Pemerintah, dalam hal ini Direktorat Jenderal Kekayaan Intelektual Kementerian Hukum dan Hak Asasi Manusia Republik Indonesia untuk semakin mempermudah dan mempermurah pendaftaran dan pencatatan KI terutama bagi para peneliti dan pelaku usaha mikro, kecil, dan menengah sehingga mereka semakin tergerak untuk mendaftarkan dan mencatatkan KI.

\section{Daftar Pustaka}

Adhi Budi Susilo, PENYELESAIAN SENGKETA PEMBATALAN PENDAFTARAN MEREK (STUDI KASUS DUA KELINCI DAN GARUDA FOOD). Jurnal Law reform - April 2011 Vol. 6 No.1.

Agus Budi Susilo, PENEGAKAN HUKUM YANG BERKEADILAN DALAM PERSPEKTIF FILSAFAT HERMENEUTIKA HUKUM (Suatu Solusi Terhadap Problematika Penegakan Hukum Di Indonesia). Jurnal Hukum dan Peradilan, Volume 2 Nomor 3 November 2013 ISSN : 2303-327.

H.R, Ridwan. (2016), Hukum Administrasi Negara. Jakarta: RajaGrafindo Persada.

Haris Yusuf \& Rahman Hasima, Perlindungan Hukum Hak Kekayaan Intelektual Masyarakat Kota Baubau, HOLREV (Halu Oleo Law Review). Volume 2 Issue 1, March 2018.

Hasima, H. Y. (2018, March), Perlindungan Hukum Hak Kekayaan Intelektual Masyarakat Kota Baubau. Halu Oleo Law Review, Volume 2(Issue 1), 335-353.

Nahrowi, N. (2014), PLAGIAT DAN PEMBAJAKAN KARYA CIPTA DALAM HAK KEKAYAAN INTELEKTUAL. SALAM: Jurnal Sosial Dan Budaya Syar-I, 1(2). https://doi.org/10.15408/sjsbs.vii2.1541,

Nourma Dewi \& Tunjung Baskoro, KASUS SENGKETA MEREK PRADA S.A DENGAN PT. MANGGALA PUTRA PERKASA DALAM HUKUM PERDATA INTERNASIONAL. Jurnal Ius Constituendum | Volume 4 Nomor 1 April 2019.

O.K Saidin. (2015), ASPEK HUKUM HAK KEKAYAAN INTELEKTUAL (Intellectual Property Rights). Jakarta: Rajawali Pers. 
Jurnal Magister Hukum Program Pascasarjana Universitas HKBP Nommensen

Volume o1 Nomor o1 Juli 2020 Halaman. 113-128

e-ISSN: 2723-164X p-ISSN: 2722-9858

http://ejournal.uhn.ac.id/index.php/opinion

Riswandi, M. H. (2017), Isu-Isu Penting Hak Kekayaan Intelektual di Indonesia. Yogyakarta: Gadjah Mada University Press.

Sanyoto. (2008, September), PENEGAKAN HUKUM DI INDONESIA. Jurnal Dinamika Hukum, Volume 8(No.3), 199-204.

Setiaji, M. \&. (2018, November), Kajian Hak Asasi Manusia dalam Negara The Rule of Law: Antara Hukum Progresif dan Hukum Positif. Lex Scientia Law Review, Volume 2(No.2), 123-138.

Susilo, A. (2018), Penegakan Hukum Yang Berkeadilan Dalam Perspektif Filsafat Hermeneutika Hukum. Jurnal Hukum dan Peradilan.

Suwari Akhmaddhian, PENEGAKAN HUKUM LINGKUNGAN DAN PENGARUHNYA TERHADAP PERTUMBUHAN EKONOMI DI INDONESIA (Studi Kebakaran Hutan Tahun 2015). Jurnal Unifikasi, ISSN 2354-5976 Vol. o3 Nomor o1 Januari 2016.

\section{Peraturan Perundang-undangan}

Undang-Undang Nomor 29 Tahun 2000 tentang Perlindungan Varietas Tanaman. Undang-Undang Nomor 30 Tahun 2000 tentang Rahasia Dagang.

Undang-Undang Nomor 31 Tahun 2000 tentang Desain Industri.

Undang-Undang Nomor 32 Tahun 2000 tentang Desain Tata Letak Sirkuit Terpadu.

Undang-Undang Nomor 28 Tahun 2014 tentang Hak Cipta.

Undang-Undang Nomor 13 Tahun 2016 tentang Paten.

Undang-Undang Nomor 20 Tahun 2016 tentang Merek dan Indikasi Geografis. 